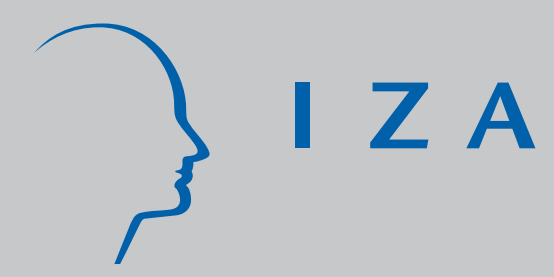

IZA DP No. 2439

The Social Assimilation of Immigrants

Domenico de Palo

Riccardo Faini

Alessandra Venturini

November 2006 


\title{
The Social Assimilation of Immigrants
}

\author{
Domenico de Palo \\ University of Rome Tor Vergata \\ Riccardo Faini \\ University of Rome Tor Vergata, \\ CEPR and IZA Bonn
Alessandra Venturini
University of Turin, CHILD, FIERI and IZA Bonn

\section{Discussion Paper No. 2439 \\ November 2006}

\author{
IZA \\ P.O. Box 7240 \\ 53072 Bonn \\ Germany \\ Phone: +49-228-3894-0 \\ Fax: +49-228-3894-180 \\ E-mail: iza@iza.org
}

Any opinions expressed here are those of the author(s) and not those of the institute. Research disseminated by IZA may include views on policy, but the institute itself takes no institutional policy positions.

The Institute for the Study of Labor (IZA) in Bonn is a local and virtual international research center and a place of communication between science, politics and business. IZA is an independent nonprofit company supported by Deutsche Post World Net. The center is associated with the University of Bonn and offers a stimulating research environment through its research networks, research support, and visitors and doctoral programs. IZA engages in (i) original and internationally competitive research in all fields of labor economics, (ii) development of policy concepts, and (iii) dissemination of research results and concepts to the interested public.

IZA Discussion Papers often represent preliminary work and are circulated to encourage discussion. Citation of such a paper should account for its provisional character. A revised version may be available directly from the author. 


\section{ABSTRACT}

\section{The Social Assimilation of Immigrants}

Policy makers in migrant-receiving countries must often strike a delicate balance between economic needs, that would dictate a substantial increase in the number of foreign workers, and political and electoral imperatives, that typically result in highly restrictive immigration policies. Promoting integration of migrants into the host country would go a long way in alleviating the trade off between economic and political considerations. While there is a large literature on the economic assimilation of immigrants, somewhat less attention has been devoted to other - and equally crucial - dimensions of migrants' integration, namely the process of social assimilation. The aim of this paper is to take a close look at migrants' social integration into the host country. We rely on the European Community Household panel $(\mathrm{ECHP})$, which devotes a full module to the role and relevance of social relations for both migrants and natives. An innovative feature of this analysis is that it relies on migrants perceptions about their integration rather than - as is typically the case in most opinion surveys - on natives attitudes toward migrants. The main results of the paper can be summarized as follows. First, migrants - particularly from non EU origins - are at a disadvantage in the fields of social relations. Even after controlling for their individual characteristics, such as age, education, family size, and employment status, they tend to socialize less than natives. Second, migrants tend to converge, albeit quite slowly, to the standard of natives. This finding highlights the risks of short term migration, where migrants tend to be constantly marginalized. Third, education has a significant impact on the type of social activities that individuals undertake. More educated people tend to relate somewhat less with their close neighbourhood, but quite intensively with the broader community. The implication for policy makers concerned about the creation of ethnic enclaves is to promote education among immigrants' community.

JEL Classification: F22, J15

Keywords: immigration, assimilation, social relationships

Corresponding author:

Riccardo Faini

Università di Roma Tor Vergata

Via Columbia 2

00133 Roma

Italy

E-mail: faini@economia.uniroma2.it

\footnotetext{
* We are grateful to Ferruccio Pastore, Franco Peracchi, Michael Eve, Irene Ponzo and Stefano Scarpetta for insightful comments. We retain responsibility for all remaining errors.
} 


\section{Introduction}

Immigration is a highly divisive issue. Opinion polls from the Eurobarometers and the Global Social Survey ${ }^{1}$ show that a large majority of natives is opposed to a further increase in migration. Policy makers must therefore strike a delicate balance between economic needs, that would dictate a substantial increase in the number of foreign workers, and political and electoral imperatives, that result in highly restrictive immigration policies.

Promoting integration of migrants into the host country would go a long way in alleviating the trade off between economic and political considerations. In Europe, unemployment rates are typically larger for migrants, fostering natives' suspicion that migrants tend to ride on the welfare state. Similarly, migrants tend to earn less than natives, even after controlling for their individual traits, fuelling concerns that they depress wage levels. Under both counts, therefore, a better integration of migrants into the host country’s labour markets would help dispel the concern about their impact and improve natives' attitudes.

Unsurprisingly, there is a large literature on the economic assimilation of immigrants starting from the pioneering work of Chiswick (1978) and the seminal contribute of Borjas (1985). The typical finding is that migrants wages tend to rise relatively faster than natives', but not rapidly enough so as to fill the initial gap.

Somewhat less attention has been devoted in the economic literature to other - and equally crucial dimensions of migrants' integration, namely the process of social assimilation. Yet, as argued by Durlauf (2002) and Durlauf and Fafchamps (2004), the extent of social relations is a key factor in the building up of social capital.

The aim of this paper is to take a close look at migrants social integration into the host country. We rely on the European Community Household panel (ECHP), which devotes a full module to the role and relevance of social relations for both migrants and natives. An innovative feature of this

\footnotetext{
${ }^{1}$ See Mayda (2006) for an in depth analysis of the determinants of natives attitudes toward migrants
} 
analysis is that it relies on migrants perceptions about their integration rather than - as is typically the case in most opinion surveys - on natives attitudes toward migrants.

\section{An overview of the literature}

The word assimilation defies a simple and generally accepted definition. In classical sociology it is intended to mean a progressive change from a more diverse to a less diverse behaviour. A more recent definition (Alba Nee 2003, pp.30-31) defines assimilation as the "attenuation of distinctions based on ethnic origin".

The Chicago School, in particular the work of Park $(1930)^{2}$, dominated the socio-political theory of assimilation. In this view, assimilation is a progressive and irreversible phenomenon. Warner and Srole (1945) first introduced the concept of a "straight line assimilation". This has been a seminal concept in the sociological literature, the basic argument being that migrants behaviour will become over time increasingly similar to that of natives. In other words, "it will converge to the American way of life". The model is quite elaborate, pointing out to many steps and different speed of adaptation in the process of assimilation, which however will push toward a uniform way of living.

This paradigm was strongly influenced by early migrants integration experience in the USA, despite their very different ethnic, cultural, religious and linguistic background. A fairly different view arose in the sixties, proposed by Glazer and Moyniham $(1970)^{3}$. Their melting pot paradigm takes a close look at the process of migrants integration in the case of New York City. The authors argue that migrants tend to assimilate to a common (American) model but at the same time increasingly retain their ethnic origin traditions.

A further radical blow to the straight line assimilation paradigm came from the work of Gans (1979, 1996). His "bumpy line theory" questions the very existence of a progressive assimilation process, highlighting that migrants' greater length of stay in the host country was not necessarily associated with a visible improvement in their economic and social conditions. Even second generation

\footnotetext{
${ }^{2}$ Contrary to a simple vision of the assimilation process, the adherents of the Chicago school noted the differing speed of adjustment for different groups, and the feedback effects on the host society.

${ }^{3}$ The volume was published already in 1963 and again in 1970 with the addition of an introduction.
} 
migrants were at risk of being marginalized. One key contribution of Gans is to focus the attention of policy makers on those policies that can favour integration.

A most recent development in the analysis is the "segmented assimilation" paradigm developed by Portes and Zou (1993). In this view, migrants assimilate in different strata of the host society. Accordingly, upward mobility can either be the outcome of individual social promotion ${ }^{4}$ or alternatively result from the action of self-supporting communities and networks which boost the influence of the disadvantaged groups.

The role of networks has been the subject of a large literature. Typically, networks are seen as instrumental in creating productive social capital, including social relations, which will in turn facilitate integration (Coleman, 1988). The role of networks is not univocal, however. While ethnic networks may promote immigrants initial integration, in the medium run they risk creating segmented enclaves with an ultimate negative effect on the process of integration in the host country. It is true that stronger network ties will allow immigrants to have more intense social relations with their peers (Granovetter, 1974). However, the transformation of social into human capital is also a function of the status and the varieties of social relations (Lin, 1995). Educated people may be at an advantage here, as they may find it easier to broaden their set of social contacts.

In Europe, contrary to the US, most of the controversy focuses on the different policies that have been adopted with respect to migrants. Two polar cases are typically mentioned. First, in France, integration was seen as a process where migrants would assimilate into the French culture, values, and ways of living. In part, this approach reflected the fact that many immigrants were already coming from former French colonies and from French speaking countries. A very different approach was followed in Germany, where migrants were not asked to assimilate into the host country society, but would be free to pursue their own way of life within the host country, through separate schools, different access to social benefits, and so on. The German model largely reflected the belief that immigration was a temporary phenomenon, after which migrants would return to their home countries. It was also influenced by the fact that migrants to Germany came from countries with very different culture, language, and religion. One could also mention a third model, dubbed the Dutch model, that emphasizes the need for a multicultural approach to integration, ruling out therefore either separation (opposite to Germany) or the need for cultural assimilation

\footnotetext{
${ }^{4}$ Downward mobility as well.
} 
(contrary to France). The French approach reminds somewhat the linear assimilation model, with a steady process of integration, managed - as in the best French tradition - by the centre. The German model is more reminiscent of the melting pot model, where however the native way of life remains dominant. However, the contrast between the two approaches is probably too stark. Moreover, over time, Germany came to realize that migrants were no longer temporary and France had to accept the fact that migrants were coming from an increasingly heterogeneous background.

The economic approach to integration resembles very closely the straight line model. Human capital theory provides the backbone to the economic approach to integration. In this set up, workers' wages reflect their human capital endowment, which can be accumulated by investing either in firm specific or in general human capital. Workers' wages are found to increase with age, education, and job tenure. Applied to the case of immigrants, the model performs quite well provided that additional variable are taken into account, namely their length of stay in the host country and their knowledge of the language there. The first variable is designed to capture the accumulation of the host country's social capital by the immigrants, while the second variable reflects his investment in a key country specific factor.

The economic analysis of migrants integration has been the subject of a very large literature. The interest in the issue reflects the belief that economic integration is key to social integration. It also arises from the concern that unemployed migrants and low wage foreigners represent a burden for the budget. Well designed integration policies could boost the immigrants contribution to the economy and alleviate the fiscal burden. Finally, economic integration, particularly in the labour market, is more easily measured ${ }^{5}$. There are however other dimensions, in addition to the labour market outcome, where migrants' integration is readily amenable to measurement, in particular housing, education, and health. Access to these services, particularly health and education, should be seen not only as directly improving migrants' position in the host country, but, equally crucially, as an investment in migrants human capital. Even housing can be indicative of the potential for rapid integration. Migrants typically settle, at least initially, in ethnic communities a fact which by itself should favour the integration of the most recent immigrants, but which in the medium term may represent a constraint more than opportunity. The formation of ethnic enclaves can indeed limit the ability, and the incentive, to acquire fluency in the host country language and can also lead to

\footnotetext{
${ }^{5}$ There is a natural bias in economic analysis for a measurable and comparable approach. Most of the time the focus is on (measurable) economic performance indicators. This is evident, to mention one case, in the Social Protection Committee "Report on Indicators in the field of poverty and social exclusion" (October 2001). Among the 18 indicators, 10 are derived from the $\mathrm{ECHP}^{5}, 9$ of which refer to different measure of income distribution", and just one use the "Self defined health status by income level".
} 
the creation of a highly segmented labour market. Health and particularly education are also keys to the integration process. Adequate schooling and training promote social inclusion by improving the language skills of (first and second generation) immigrants and by providing a common cultural background to natives and foreigners.

Yet, there are other relevant dimensions of the integration process, in addition to the labour market performance and the access to adequate housing, education, and health services. In particular, the use of leisure, while often neglected in traditional analyses, represents a crucial factor in the process of migrants integration. This is not simply because an active social life can have positive spillovers on the labour market performance of individuals. More crucially, it reveals migrants ability to integrate into the social life of the host country.

In this paper, we rely, for the purpose of empirical analysis, on the European Community Household Panel. This is a large household survey conducted in a number of European countries, that yields internationally comparable information on both natives and migrants. We will see that the ECHP provides a wider set of information about migrants integration that could be fruitfully used to measure migrants performance, and so go beyond traditional analyses. In particular, the ECHP includes a full module on social relations and, hence, allows a meaningful comparison of the breadth of social relations between migrants and natives using an internationally comparable and statistically representative sample ${ }^{6}$. It then becomes possible to measure the role of factors such as education and migrants' length of stay. The topic is taken up in the next section.

\section{The European Community Household Panel}

The ECHP is a multi-country longitudinal survey based on a standardized questionnaire. The survey involves annual interviews of a representative sample of households and individuals in a number of European countries. The total duration of the ECHP is 8 years, running from 1994 to 2001. In the first wave (1994), a sample of almost 130,000 people aged 16 years and more was interviewed in

\footnotetext{
${ }^{6}$ The ECHP provides valuable information on other key aspects of integration. Concerning housing, the ECHP includes a module on the size of the house and its characteristics. Unfortunately, no information on the ethnic characteristics of the neighbourhood is provided, thereby preventing any meaningful analysis of the role of ethnic enclaves. Information on education is more comprehensive, as it includes also data on both general and vocational education for both first and second generation immigrants. Finally, the ECHP also offers detailed data on the health status and the access to health services by natives and immigrants. We plan to use this information in future work.
} 
the then 12 Member States of the European Union (EU). Austria, Finland and Sweden were added later.

The target population of the ECHP consists of people living in private households throughout the national territory of each country. The definition of household is based on the standard criteria of "sharing the same dwelling" and "common living arrangements". A sample person is anybody in the first wave who is still alive, plus children born afterwards in a sample household. Sample persons are eligible for personal interview if they are aged 16+ on December 31 of the year before the survey.

The main advantage of this panel is that sample households and individuals are followed over time, with some exclusion restrictions. Its shortcoming is the lack of sample refreshment. As is stands, the panel can capture some aspects of demographic change - the natural rate of population growth but is bound to miss other components, namely the inflow of new immigrants.

\section{a) Social relations in the ECHP}

The aim of this paper is to take a close look at the extent of social relations of immigrants and compare it to that of natives. We will then relate our findings to a number of conditioning factors, such as age, marital status, educational level, activity status and household sample size.

The ECHP devolves a full individual module ${ }^{7}$ to the issue of social relations. We focus on two main questions $^{8}$ : a) "how often do you talk to your neighbour?" (variable PR003) and b) "how often do you meet friend or relatives not living with you, whether here at home or elsewhere?" (variable PR004).

For both questions, responses are coded in 5 different categories: on most days, once or twice a week, once or twice a month, less often than once a month and never. In France these categories are restricted to 3 broader classes: often corresponds to once or twice a week, sometimes to once or twice a month, rarely to less than once a month.

\footnotetext{
${ }^{7}$ The module is entitled PR- SOCIAL RELATION

${ }^{8}$ There is another interesting question in the module: "During the last week, have you spoken, even if only on the phone, to anyone outside your household?"(variable PR005). Unfortunately, the size of the sample is too limited to allow a meaningful empirical analysis.
} 
For both variables, data availability is plentiful. In Tables A1 and A2 in the appendix we report the relevant information, for natives (panel A) and for immigrants (panel B). There is a non negligible amount of missing data for Belgium, Portugal and Spain. Yet, the average response rate is about 99\%. We find very similar results when we consider the immigrants sample (panel B).

In Table 1 we present summary statistics for our dependent variables. In columns 1 and 2 we report the percentage of individuals that answer either "on most days" or "once/twice a week" to the question "how often do you talk to your neighbours?". We label this individual as "high socializers". Column 1 refers to immigrants, column 2 to natives. In columns 3 and 4 we report the same information for high socializers defined on the basis of the second question "how often do you meet friend or relatives not living with you, whether here at home or elsewhere?". For both questions, we distinguish among individuals as a function of their education (rows 1-3), their sex, their length of stay (rows 5-8), and their employment status.

\section{$<<$ Insert table 1 $>>$}

Consider first the effect of education. Interestingly enough, it appears that for both immigrants and natives individuals with a highest of education have less intensive social relations when we focus on the first question, while the opposite is true for the second question. Accordingly, highly educated people tend to socialize relatively more outside of their neighbourhood. Clearly, when assessing the extent of social relations, it will be essential to control for education.

Employed individuals have less intensive relationships than males. Interestingly enough, the difference is more marked for the immigrants sample:

The length of stay in the host country represents a key factor for the purpose of assessing migrants' integration. We distinguish four groups of migrants, as a function of the time they have spent in the receiving country: less than 5 years, between 6 and 15 years, between 15 and 25 years, and more than 25 years. For both questions, we find that migrants' social relations tend to increase with their length of stay in the host country. The percentage of "socializers" rises from $62.3 \%$ for immigrants that have been in the host country for less than 5 years to $70 \%$ for those who have been there for more than 15 years. The correlation flattens out however for migrants that have been in the receiving country for a very long time (more than 25 years).

In tables 2 and 3, we present a more detailed analysis of social relations, by distinguishing between receiving countries and presenting the full disaggregation of the dependent variable. We find that in 
Ireland, Spain and Portugal social relationships are relatively more intense than in other countries for both natives and immigrants. For the first question ("how often do you talk to your neighbour?"), the percentage of socializers in these countries is always higher than $85 \%$ for natives and $75 \%$ for immigrants, against a sample average of $76 \%$ and $68 \%$ respectively. Italy is close to the sample average,

$<<$ Insert table 2-3 $>>$

\section{b) The determinants of social activities}

We have seen how the degree of social relations seems to vary with the level of education, sex, employment condition, and the migrant's length of stay in the host country. In this section, we take a close look at these variables. We then turn to a more formal econometric analysis.

Consider education, first. The ECHP recodes the ISCED classification in three broader classes: "recognized third level education" (ISCED 5-7), "second stage of secondary level education" (ISCED 3) and "less than second stage of secondary education" (ISCED 0-2). It is important to note that this information is collected only when the person enters the survey, but it is not updated until wave 5 (1998). Starting from 1998, individuals that are still at school are not classified separately. Table 4 shows the relevant data for natives (panel A) and for immigrants (panel B). Two facts stand out. First, immigrants have a higher level of education than natives. On average, $22.5 \%$ of immigrants hold a higher education degree, against $16.4 \%$ for natives. Conversely, only $41.5 \%$ of immigrants have less than a secondary school degree versus $50.8 \%$ for natives. Second, there are substantial differences among countries. Denmark, Belgium, and Spain are particularly successful in attracting highly educated migrants. Moreover, opposite to what a traditional factor endowment model would suggest, countries with a low level of educational achievements among natives (Italy, Portugal, and Austria) fail to attract highly qualified migrants. However, for Portugal and Austria, but not for Italy, migrants' educational levels are substantially higher than those of natives.

\section{$<<$ Insert table4>>}

The activity status is constructed from the variable "ILO main activity status at the time of interview", which distinguishes 5 different categories. We prefer to recode the variable in employed and not employed. In particular, we define as employed an individual who is working either 
normally or currently (i.e., we make no distinction between part time and full time employment ${ }^{9}$ ). The residual category includes discouraged worker, unemployed or economically inactive individuals. In general (table 5), the employment rate is slightly lower for immigrants than for natives. This figure however hides substantial differences among countries. In Belgium, France, Denmark, and Austria employment rates among immigrants are substantially lower than among natives. The difference is particularly marked in Belgium (14\%) and Denmark (19\%) ${ }^{10}$. Had we conditioned on gender as well the difference would be even more pronounced.

\section{$<<$ Insert table5 $>>$}

The length of stay is, as noticed earlier, a key variable for the purpose of our analysis. Table 6 reports the relevant data. The average length of stay is 22.7 years, slightly higher for males (23.3) than for females (22.2). There are revealing differences between sending countries, with France and Belgium featuring the longest average stay and Denmark, Spain, Portugal, and Austria the shortest ones. Clearly, this reflects the different immigration history within the EU, where France and Belgium have the longest tradition as a receiving countries, while most others have only recently become targets of substantial immigration inflows.

\section{$<<$ Insert table 6>>}

\section{Empirical analysis}

Our working hypothesis is that the degree of social relation is a function of both individual and household characteristics. In the former group, we include age, education, gender, employment conditions, and marital status; in the latter, household size. We also control both for the country of destination, under the assumption that the degree of social relations may not be the same among the host countries, and for time effects, to allow for common shocks across all individuals ${ }^{11}$. We also include in the regression a dummy variable to control for the immigrant status. Alternatively, we run separate regressions for immigrants and natives.

We have no strong a priori on the effect of these covariates. However, based on the findings of table 1, we would presume that the degree of social relations falls with education (at least when measured

\footnotetext{
${ }^{9} \mathrm{We}$ are aware of the fact that the precariousness of employment conditions may affect migrants relatively more. We plan to analyze this aspect in future work.

${ }^{10}$ This issue is taken up in the companion paper by De Palo and Peracchi (2006) in print as World Bank Policy Research Working Paper.

${ }^{11}$ The implicit assumption is that the degree of social assimilation is independent of the region of origin. We shall soon relax this assumption and also examine the significance of interaction effects between countries of destination and regions of origin.
} 
by question 1 "how often do you talk to your neighbour?"), but rises with the length of stay in the host country. We also expect employed individuals to socialize less.

More formally, we run the following (logit) regression:

$D_{\mathrm{it}}=\alpha_{0}+\alpha_{1} \mathrm{HS}+\alpha_{2} \mathrm{AGE}+\Sigma_{\mathrm{s}} \alpha_{3 \mathrm{~s}} \mathrm{ED}_{\mathrm{s}}+\alpha_{4}$ GENDER $+\alpha_{5}$ EMPL $+\alpha_{6}$ SPOUSE $+\alpha_{7} \mathrm{M}$

where $D_{i t}$ takes a value of 1 if at time $t$ individual i's answer to the relevant questions is either "most days" or "once/twice a weeks", HS is the size of the household, AGE is the age of the respondent, $\mathrm{ED}_{\mathrm{s}}$ are different educational levels, EMPL takes a value of 1 if the individual is employed, SPOUSE is equal to 1 if the spouse lives in the household, and M takes a value of 1 if the individual is foreign born. We include in the regression, but do not report the relevant coefficients, also a set of time and country dummies.

In Table 7, we consider the responses to question 1 ("how often do you talk to your neighbour?"). We find (column 1) that younger, more educated, male, foreign born, and employed individuals tend to socialize less. The coefficient on the immigrant dummy is negative and highly significant, suggesting that even after controlling for individual traits, immigrants happen to socialize less. In column 2, we distinguish migrants according to their origin, namely whether they come from EU or non EU countries. We find that the negative impact of the immigrant status on individual social activities vanishes for EU migrants, but is now substantially stronger for non EU migrants. Clearly, the issue of social integration is more relevant for non EU migrants that are more likely to come to the host country with a fairly different cultural and religious background. In columns 3 to 5 , we run three separate regressions, respectively for natives, EU immigrants, and non EU immigrants. For the latter two groups, we include among the regressors the migrant's length of stay in the host country. The results for natives (column 3), EU immigrants (column 4) and non EU immigrants (column 5) are very similar to those for the pooled sample in column 1. By and large, all the covariates, in particular age, education, employment and gender, seem to have very similar effects for all groups.

The length of the stay in the host country is relevant only for foreign born individuals. This is a key variable in the analysis of the process of integration. The main finding here is that the degree of social relation rises quite steeply with the length of stay in the host country for the non EU immigrants, but does much less so for immigrant from other EU countries. The gap between EU 
and non EU immigrant increases somewhat for short, less than six years, stays, but then diminishes quite rapidly and is fully reversed after 6 years. Finally, in the last column, we compare non EU immigrants only with natives. We find again that immigrants are initially at a disadvantage, but that the gap shrinks steadily over time until it is basically nil after a relatively long, more than 15 years, stay in the host country.

\section{$<<$ Insert table 7 >>}

In table 8, we exploit the ordinal nature of the dependent variable and estimate an ordered logit model. The key finding that migrants, particularly from non EU origins, are less involved in social activities but tend to converge to the standard of other groups survives with this procedure ${ }^{12}$. When we compare non EU immigrants with natives (column 6) the gap is reversed after 15 years of stay in the host country.

\section{$<<$ Insert table8 $>>$}

Finally, in table 9, we turn to the second question "how often do you meet friend or relatives not living with you, whether here at home or elsewhere?". Three facts stand out. First, greater education is no longer associated with a lower degree of social activities. Actually, the opposite holds, suggesting that social activities of more educated people takes place mainly outside their neighbourhood. As in Lin (1995), educated individuals will tend to broaden their social relations as a way to build more social and human capital. Second, being employed is no longer a significant constraint to social activities, at least for migrants. Third, migrants seems to be less at a disadvantage. When we disaggregate between EU and non EU migrants, however, we find again that the latter group has less intensive social relations. However, as for table 7, the gap with the other groups declines over time, as the length of stay in the host country increases (column 6). Table 10 relies on an ordered logit procedure. Again, highly educated individual tend to favour this form of social relation, while migrants converge to the standards of other groups.

\section{$<<$ Insert tables 9 and $10>>$}

How robust are our results? We have relied so far on a fairly basic econometric specification where data for different individuals are simply pooled. Moreover, no attempt was made to control for the migrants' different regions of origin. In what follows, we address both issues. We use a random effect specification and also control for the migrants' region of origin. The results for question 1 ("how often do you talk to your neighbour?") are reported in table A3 in the appendix. The coefficients are somewhat larger than in table 7, but their sign and pattern are basically unchanged. All our previous conclusions survive therefore to this somewhat more refined econometric

\footnotetext{
${ }^{12}$ We come to the very same conclusion if, as in table 7 , we do not exploit the ordinal nature of the dependent variable but rely on a different and broader definition of "high socializers" by including in this group all individual whose response to the question 1 ("how often do you talk to your neighbour?") is different from "never".
} 
treatment. The same finding holds when we consider question 2 ("how often do you meet friend or relatives not living with you, whether here at home or elsewhere?"), as can be seen from table A4.

A more subtle issue relates to selectivity. As noticed earlier, the ECHP is a closed panel. Individuals may however drop out of the panel. In turn, the probability of dropping from the panel may be related to the degree of social relations achieved by the individual. Migrants in particular may be more likely to return home (or to move elsewhere, as also natives would do) if they fail to assimilate into the social life of the host country. Conversely, migrants that plan an early return to their home country will tend to socialize less. On both counts, therefore, migrants that do not drop from the panel are likely to be "high socializers". Therefore, the finding that the degree of social relations rises with the length of stay may not reflect an assimilation effect, but simply pick up the fact that individuals that socialize less are more likely to drop out of the panel. To control for this possibility, we rely on a standard Heckman procedure. As identifying variables we use the number of visits for the interview (under the plausible assumption that individuals are more likely to drop out of the panel when interviews are very time consuming) and a set of time dependent dummies for each immigrants region of origin, with the view to picking up the effect that changing conditions in the home country may have on the return decision of migrants. Both sets of variables turn to be highly significant in the selection equation. Interestingly enough, though, the previous results about the determinants of social life are basically unchanged (tables A5 and A6). The selectivity correction is quite significant for natives, but not so for immigrants, suggesting that for this group, the degree of social activities and the return decision are largely independent. More crucially, we find that, even after controlling for sample attrition, the key finding of the paper holds: immigrants tend to assimilate into the social life of the host country the longer their length of stay there.

\section{Conclusions}

The aim of this paper was to analyse the process of migrants' integration into the host country from a social point of view. Our paper contributes to the existing literature in two main ways. First, it relies on internationally comparable information for the purpose of assessing the degree of social integration. Second, it uses migrants own perceptions about their integration rather than natives attitudes toward migrants. 
The main results of the paper can be summarized as follows. First, migrants - particularly from non EU origins - are at a disadvantage in terms of social relations. Even after controlling for their individual characteristics, such as age, education, family size, and employment status, they tend to socialize less than natives. Unfortunately, we have no information on the ethnic characteristics of the neighbourhood where individuals live and cannot assess therefore whether migrants that live in ethnically homogeneous communities tend to socialize more. This is an important shortcoming of our analysis. Second, migrants tend to converge, albeit quite slowly, to the standard of natives. This finding highlight the risks of short term migration, where migrants tend to be constantly marginalized. Third, education has a significant impact on the type of social activities that individuals undertake. More educated people tend to relate somewhat less with their close neighbourhood, but socialize quite intensively with the broader community.

The implication for policy makers concerned about the creation of ethnic enclaves is to promote education among immigrants' community. If our findings are correct, educated people will broaden their social horizon and relate more intensively with individuals outside their close neighbourhood. Our findings also cast a shadow on the impact of temporary migration schemes. Indeed, they may work at cross purpose with the objective of social assimilation, not only by discouraging immigrants from investing in capital specific to the hosting country, but also by artificially cutting short the immigrant's length of stay in the host country. 


\section{References}

Alba, R., Nee V., 2003, Remaking the American Mainstream. Assimilation and Contemporary Immigration, Cambridge,Mass.: Harvard University Press.

Borjas, G., 1985, Self selection and the earnings of immigrants, American Economic Review, 77 : 531-553.

Chiswick, B., 1978, The effects of Americanization on the earnings of foreign born men, Journal of Political Economy, 86: 897-921.

Coleman, D. 1988 Social Capital in the Creation of Human capital American Journal of Sociology, n.94, supplement, 95-120.

De Palo, D., Peracchi F. 2006 fothcoming, Labor market outcomes of natives and immigrants:

Evidence from the EHCP, as World Bank Policy Research Working Paper.

Durlauf, S., Fafchamps M. 2004, Social capital, NBER Working Paper n. 10485, Cambridge, MA.

Durlauf ,S. 2002, On the empirics of social capital, Economic Journal, 112, F459-479.

Gans, H.,1979, Symbolic Ethnicity: The Future of Ethnic Groups and Cultures in America, Ethnic and Racial Studies, 2(1): 1-20.

Gans, H., 1996, Second-Generation Decline. Scenarios for the Economic and Ethnic Futures of the post-1965 American immigrants, in Immigration and Integration in Post-Industrial Societies. Theorical analysis and policy-related research, ed Carmon N. 65-85. Basingstoke:Macmillan,

Glazer, N., Moynihan D., 1970, Beyond The Melting Pot, Cambridge, Mass. MIT Press.

Granovetter, M. 1974 Getting a job Chicago: The University of Chicago

Lin, N., 1995, Les resources socials: une théorie du capital sociale Review françaises de sociologie, 36, n.4 : 685-704.

Locatelli, M., Moscato V., Pasqua S., 2001, The European Community Household Panel (ECHP): Elements for Users with Special Focus on labour and Household Economics, CHILD W.P.n.24.

Mayda, A.M., 2006, Who is against immigration? A cross country investigation of individual attitudes toward immigrants, Review of Economics and Statistics, forthcoming.

Park, R.E., 1930, Assimilation, Social, in Seligman E. and Johnson A. (eds.) Encyclopaedia of Social Sciences, New York: Macmillan

Porte,s A., Zou M., 1993, The New Second Generation: Segmented Assimilation and its Variants Among Post-1965 Immigrant Youth, The Annals of the American Academy of Political and Social Sciences 530:74-96.

Social Protection Committee, 2001, Report on Indicators in the field of poverty and social exclusion, Commission of the European Union, October. 
Warner, W.L., Srole L., 1945, The Social Systems of American Ethnic Groups, New Haven, YaleUniversity Press. 
Table 1: Anatomy of the "high socializers" (Percentage of affirmative answers)

\begin{tabular}{|c|c|cc|cc|}
\cline { 3 - 7 } \multicolumn{2}{c|}{} & \multicolumn{2}{c|}{$\begin{array}{c}\text { How often do you } \\
\text { talk to neighbours? }\end{array}$} & \multicolumn{2}{c|}{$\begin{array}{c}\text { How often do you } \\
\text { meet people? }\end{array}$} \\
\cline { 3 - 7 } \multicolumn{2}{c|}{} & Immigrants & Natives & Immigrants & Natives \\
\hline Education: & Highest & 65.2 & 68.6 & 75.8 & 80.8 \\
& Intermediate & 70.6 & 74.7 & 76.6 & 80.1 \\
& Basic & 70.1 & 82.8 & 70.2 & 79.2 \\
\hline Sex & Female & 71.1 & 73.3 & 71.7 & 78.4 \\
\hline Length of stay & $<\mathbf{5}$ years & 62.3 & - & 71.8 & - \\
& $\mathbf{6 < x < 1 5}$ years & 67.9 & - & 71.8 & - \\
& $\mathbf{1 5 < x < 2 5}$ years & 70.0 & - & 76.8 & - \\
& $>\mathbf{2 5}$ years & 69.6 & - & 73.2 & - \\
\hline Employment & & & & & \\
status & Employed & 58.2 & 61.9 & 61.2 & 63.4 \\
\hline & Total & 68.8 & 76.9 & 74.3 & 80.4 \\
\hline
\end{tabular}

Source: Authors'calculations based on ECHP data; - not applicable

Table 2: "How often do you talk to neighbours?" (Percentage of affirmative answers)

$\underline{\text { Panel A - Natives }}$

\begin{tabular}{|c|c|c|c|c|c|c|}
\hline $\begin{array}{r}\text { Country } \\
\text { code }\end{array}$ & most days & $\begin{array}{c}\text { How often } \\
\text { once/twice } \\
\text { a week }\end{array}$ & $\begin{array}{l}\text { talk to nei } \\
\text { once/twice } \\
\text { a month }\end{array}$ & $\begin{array}{l}\text { ghbours } \\
\text { less often }\end{array}$ & never & Total \\
\hline Austria & 38.16 & $42.0 \odot$ & 12.99 & 4.64 & 2.21 & 100.00 \\
\hline Belgium & 29.21 & 39.94 & 17.50 & 8.97 & 4.38 & 100.00 \\
\hline Denmark & 30.09 & 41.47 & 14.84 & 9.05 & 4.55 & 100.00 \\
\hline France & $\odot . \odot \odot$ & 45.72 & 31.22 & 23.05 & $\odot . \odot \odot$ & 100.00 \\
\hline Ireland & 56.75 & 32.29 & 7.24 & 2.15 & 1.57 & 100.00 \\
\hline Italy & 51.12 & 28.57 & 9.86 & 5.61 & 4.83 & 100.00 \\
\hline Portugal & 59.25 & 27.55 & 8.10 & 3.04 & 2.07 & 100.00 \\
\hline Spain & 65.88 & 23.16 & 5.89 & 2.89 & 2.19 & 100.00 \\
\hline Total & 44.03 & 32.91 & 12.94 & 7.44 & 2.69 & 100.00 \\
\hline
\end{tabular}

Panel B - Immigrants

Country

How often talk to neighbours

\begin{tabular}{|c|c|c|c|c|c|c|}
\hline code & most days & $\begin{array}{c}\text { once/twice } \\
\text { a week }\end{array}$ & $\begin{array}{c}\text { once/twic } \\
\text { a month }\end{array}$ & Less ofte & never & Total \\
\hline Austria & 35.82 & 38.91 & 12.94 & 7.13 & 5.19 & 100.00 \\
\hline Belgium & 35.27 & 38.60 & 13.66 & 8.09 & 4.38 & 100.00 \\
\hline Denmark & 31.96 & 36.88 & 13.75 & 11.52 & 5.89 & 100.00 \\
\hline France & $0.0 \odot$ & 47.26 & 32.65 & 20.09 & $0.0 \odot$ & 100.00 \\
\hline Italy & 45.88 & 30.43 & 13.46 & 5.60 & 4.63 & 100.00 \\
\hline Ireland & 50.40 & 34.55 & 8.67 & 3.44 & 2.94 & 100.00 \\
\hline
\end{tabular}




\begin{tabular}{r|rrrr|r|r} 
Portugal & 42.64 & 34.69 & 12.82 & 5.08 & 4.77 & 100.00 \\
Spain & 55.07 & 27.77 & 8.38 & 4.05 & 4.73 & 100.00
\end{tabular}

Total

30.33

38.46

17.78

10.13

$3.30 \mid$

100.00

Source: Authors'calculations based on ECHP data.

Table 3: Statistics for "How often do you meet people?"

(Percentage of affirmative answers)

$\underline{\text { Panel A - Natives }}$

\begin{tabular}{|c|c|c|c|c|c|c|}
\hline \multirow{2}{*}{$\begin{array}{r}\text { Country } \\
\text { code }\end{array}$} & \multicolumn{5}{|c|}{ How often meet people } & \multirow[b]{2}{*}{ Tota] } \\
\hline & most days & $\begin{array}{c}\text { once/twice } \\
\text { a week }\end{array}$ & $\begin{array}{c}\text { once/twice } \\
\text { a month }\end{array}$ & less often & never | & \\
\hline Denmark & 24.93 & 55.59 & 17.47 & 1.96 & 0.06 & 100.00 \\
\hline Belgium & 32.27 & 40.43 & 19.77 & 6.92 & 0.61 & 100.00 \\
\hline France & $\odot . \odot \odot$ & 67.70 & 25.11 & 7.18 & $\odot . \odot \odot$ & 100.00 \\
\hline Ireland & 71.33 & 24.81 & 3.25 & 0.52 & 0.09 & 100.00 \\
\hline Italy & 47.76 & 32.25 & 13.35 & 4.63 & 2.02 & 100.00 \\
\hline Spain & 69.30 & 23.68 & 5.23 & 1.53 & $\odot .26$ & 100.00 \\
\hline Portugal & 39.27 & 37.60 & 13.85 & 7.46 & 1.82 & 100.00 \\
\hline Austria & 16.71 & 54.11 & 24.51 & 3.64 & 1.03 & 100.00 \\
\hline Total & 40.59 & 39.78 & 14.33 & 4.41 & $0.89 \mid$ & 100.00 \\
\hline
\end{tabular}

$\underline{\text { Panel B - Immigrants }}$

\begin{tabular}{|c|c|c|c|c|c|c|}
\hline \multirow{2}{*}{$\begin{array}{r}\text { Country } \\
\text { code }\end{array}$} & \multicolumn{5}{|c|}{ How often meet people } & \multirow[b]{2}{*}{ Total } \\
\hline & most days & $\begin{array}{c}\text { once/twice } \\
\text { a week }\end{array}$ & $\begin{array}{c}\text { once/twice } \\
\text { a month }\end{array}$ & less often & never I & \\
\hline Denmark & 28.50 & 48.44 & 18.17 & 4.54 & 0.36 & 100.00 \\
\hline Belgium & 35.61 & 42.04 & 16.63 & 4.95 & 0.77 & 100.00 \\
\hline France & $\odot .0 \odot$ & 59.81 & 30.53 & 9.66 & $\odot .00$ & 100.00 \\
\hline Ireland & 68.03 & 25.74 & 4.34 & 1.75 & $\odot .15$ & 100.00 \\
\hline Italy & 41.80 & 35.40 & 15.49 & 4.95 & 2.37 & 100.00 \\
\hline Spain & 61.69 & 27.84 & 6.69 & 3.18 & 0.61 & 100.00 \\
\hline Portugal & 38.67 & 36.60 & 13.77 & 9.32 & 1.64 & 100.00 \\
\hline Austria & 20.16 & 51.77 & 23.08 & 3.75 & $1.24 \mathrm{i}$ & 100.00 \\
\hline Total & 29.72 & 44.56 & 18.93 & 6.04 & $0.76 \mid$ & 100.00 \\
\hline
\end{tabular}

Source: Authors' calculations based on ECHP data. 


\section{Table 4: Educational levels for migrants and natives (Percentage of affirmative answers)}

\section{$\underline{\text { Panel A - Natives }}$}

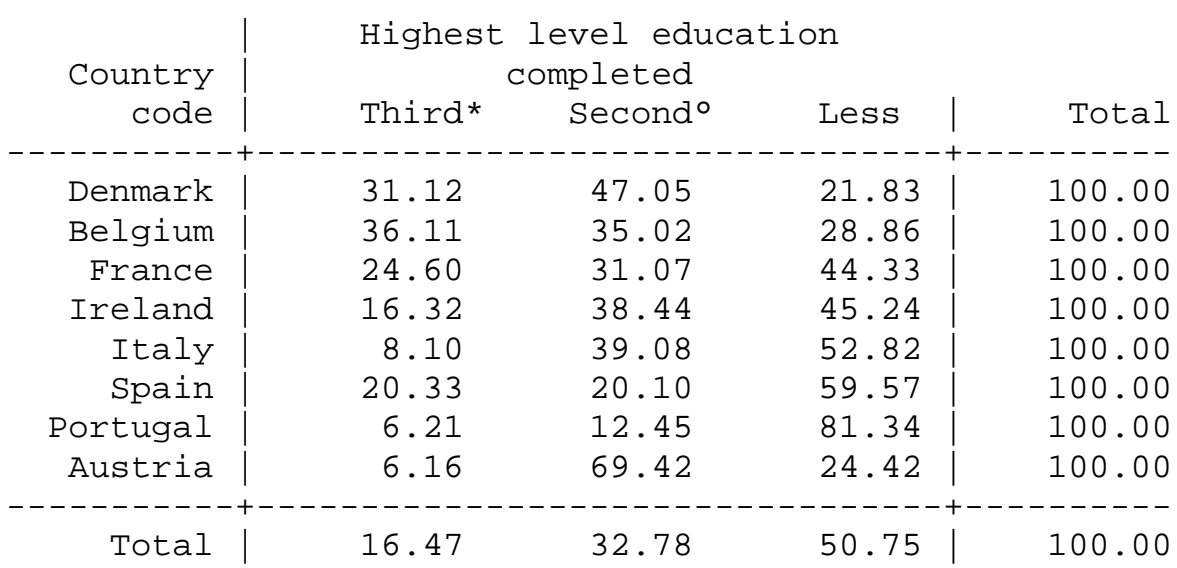

$\underline{\text { Panel B - Immigrants }}$

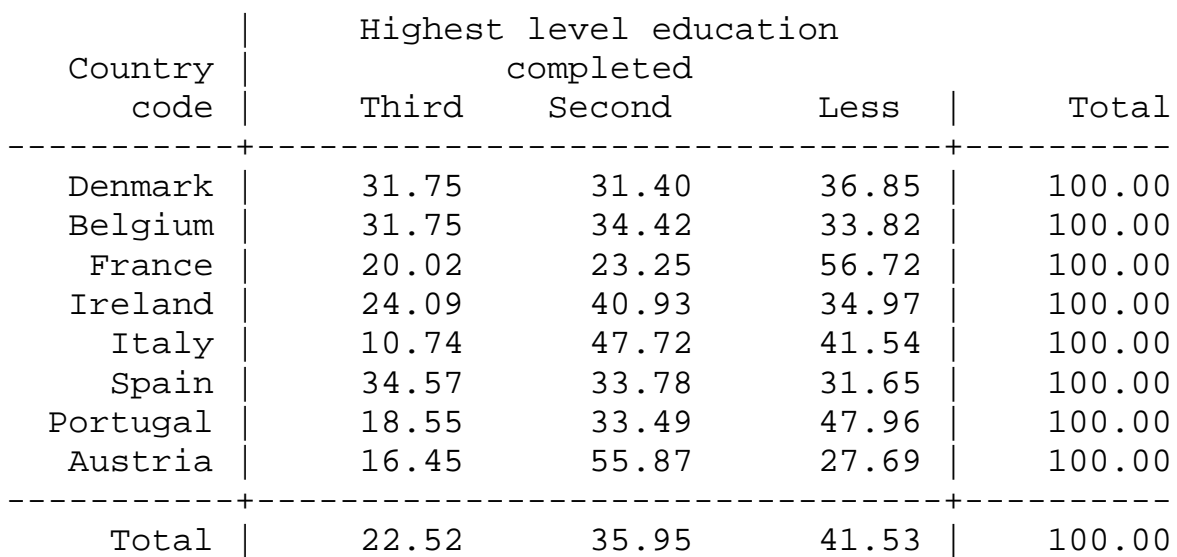

Source: Authors' calculations based on ECHP data.

- Third: higher than secondary school degree;

- Second: secondary school degree;

- Less: less than secondary school level. 
Table 5: Employment status

(Percentage of affirmative answers)

$\underline{\text { Panel A - Natives }}$

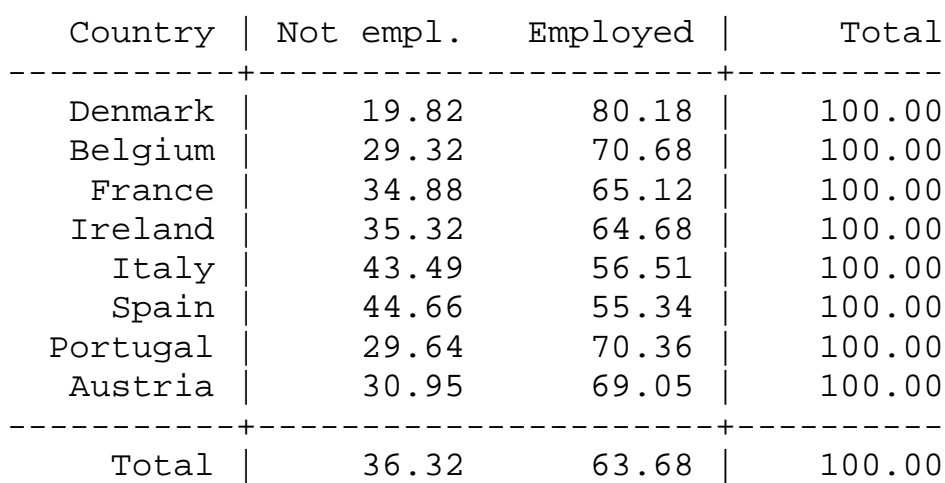

$\underline{\text { Panel B - Immigrants }}$

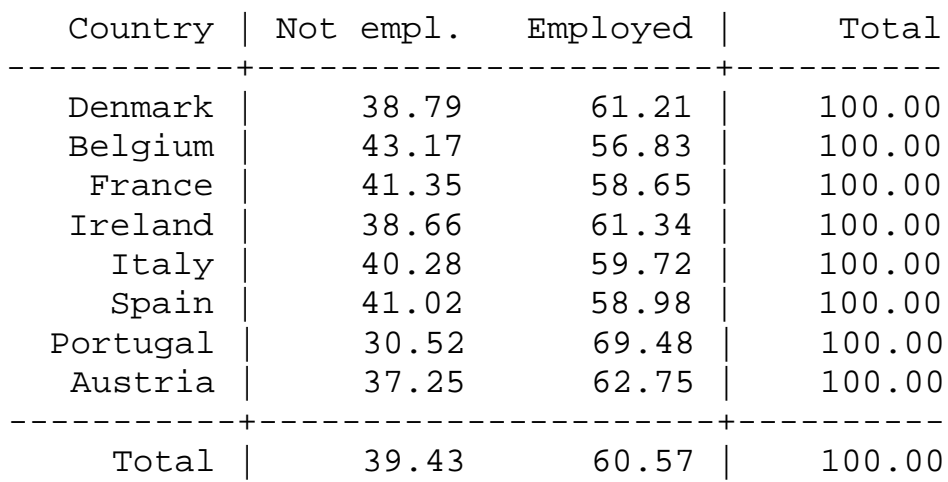

Source: Authors' calculations based on ECHP data.

Table 6: Migrants' length of stay in the host country

(Average years)

\begin{tabular}{r|ccc} 
Country & Male & Female & Total \\
\hline Denmark & 17.3 & 19.0 & 18.2 \\
Belgium & 26.6 & 24.5 & 25.5 \\
France & 27.7 & 25.8 & 26.8 \\
Ireland & 22.6 & 23.7 & 23.2 \\
Italy & 25.3 & 22.1 & 23.4 \\
Spain & 17.8 & 17.9 & 17.8 \\
Portugal & 20.4 & 20.3 & 20.3 \\
Austria & 18.5 & 18.8 & 18.7 \\
& & & \\
Total & 23.2 & 22.2 & 22.7
\end{tabular}

Source: Authors' calculations based on ECHP data 
Table 7

The determinants of social relations: "How often do you talk to your neighbour?" (logit model) ${ }^{1}$

\begin{tabular}{|c|c|c|c|c|c|c|}
\hline COVARIATES & POOLED & POOLED & NATIVES & $\begin{array}{c}\text { EU } \\
\text { IMMIGRANTS }\end{array}$ & $\begin{array}{c}\text { NON } \\
\text { EU IMM. }\end{array}$ & POOLED $^{2}$ \\
\hline Household size & $0.049 * * *$ & $0.050 * \star \star$ & $0.050 * * \star$ & 0.061 & 0.024 & 0.049 *** \\
\hline Age & $0.014^{* * *}$ & $0.014^{* * *}$ & $0.013^{* * *}$ & $0.019 * * *$ & 0.002 & $0.013 * * *$ \\
\hline Highest ed. & $-0.370 * \star \star$ & $-0.369 * \star *$ & $-0.367 * \star \star$ & $-0.326 *$ & $-0.341^{* * *}$ & $-0.368 * * *$ \\
\hline Intermediate ed. & $-0.150 * * *$ & $-0.150 * * *$ & $-0.148 * \star \star$ & $-0.198 *$ & $-0.192^{*}$ & $-0.150 * * *$ \\
\hline Gender & $0.218 * * *$ & $0.218 * \star \star$ & $0.221 * \star \star$ & 0.175 & $0.173 *$ & $0.220 * \star \star$ \\
\hline Employment & $-0.237 * \star \star$ & $-0.238 * \star \star$ & $-0.236 * \star \star$ & $-0.490 * \star \star$ & $-0.230 * *$ & $-0.235 * \star \star$ \\
\hline Spouse & $0.386 * * *$ & $0.386 * * *$ & $0.398^{\star \star *}$ & 0.128 & $0.253^{* *}$ & $0.395^{* \star *}$ \\
\hline Immigrant & 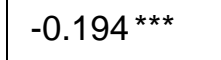 & & - & & & \\
\hline Immigrant EU & & -0.054 & - & & & \\
\hline Immigrant non EU & & $-0.293 * * *$ & - & & & $-0.778 * * \star$ \\
\hline Length $<5$ years & & & - & 0.322 & 0.199 & 0.197 \\
\hline Length $6-15$ years & & & - & 0.074 & $0.587 * * *$ & $0.542^{* * *}$ \\
\hline Length $16-25$ years & & & - & 0.170 & $0.801 * * *$ & $0.745^{* * *}$ \\
\hline Constant & Yes & Yes & Yes & Yes & Yes & Yes \\
\hline Country dummies & Yes & Yes & Yes & Yes & Yes & Yes \\
\hline Time dummies & Yes & Yes & Yes & Yes & Yes & Yes \\
\hline Pseudo R2 & 0.119 & 0.119 & 0.119 & 0.101 & 0.088 & 0.120 \\
\hline Obs: & 442929 & 442929 & 424842 & 7865 & 10064 & 434906 \\
\hline \multicolumn{7}{|c|}{ Legend: ${ }^{\star} p<0.05 ;{ }^{* \star} p<0.01 ;{ }^{* \star *} p<0.001$} \\
\hline
\end{tabular}


Table 8

The determinants of social relations: “How often do you talk to your neighbour?" (ordered logit model)

\begin{tabular}{|c|c|c|c|c|c|c|}
\hline COVARIATES & POOLED & POOLED & NATIVES & \begin{tabular}{|c|} 
EU \\
IMMIGRANTS \\
\end{tabular} & $\begin{array}{c}\text { NON } \\
\text { EU IMM. }\end{array}$ & POOLED ${ }^{1}$ \\
\hline Household size & $0.037^{* * *}$ & $0.037^{* * \star}$ & $0.037^{* \star *}$ & 0.054 & 0.009 & 0.036 *** \\
\hline Age & $0.011^{* * *}$ & $0.011 * * *$ & $0.011 * * *$ & $0.011^{* *}$ & 0.002 & $0.011^{* * \star}$ \\
\hline Highest ed. & $-0.452 * * *$ & $-0.45^{* \star *}$ & $-0.449 * * *$ & $-0.512^{* \star *}$ & $-0.358 * \star *$ & $-0.449 * * *$ \\
\hline Intermediate ed. & $-0.234 * * *$ & $-0.234 * * *$ & $-0.234 * * *$ & $-0.3^{* * *}$ & $-0.18 * \star$ & $-0.234^{* * *}$ \\
\hline Gender & $0.208 * * *$ & $0.208 * * *$ & $0.211 * * *$ & 0.128 & $0.168 * *$ & 0.21 *** \\
\hline Employment & $-0.302 * * *$ & $-0.302 * \star *$ & $-0.3^{* \star *}$ & $-0.516 * \star \star$ & $-0.303 * * *$ & $-0.3^{* * *}$ \\
\hline Spouse & $0.273^{* * *}$ & $0.273^{* \star *}$ & $0.278 * \star *$ & 0.046 & $0.285^{* \star *}$ & $0.28 * * *$ \\
\hline Immigrant & $-0.182 * * *$ & & - & & & -0.761 *** \\
\hline Immigrant EU & & -0.054 & - & & & \\
\hline Immigrant non EU & & $-0.28 * * *$ & - & & & \\
\hline Length $<5$ years & & & - & $0.323 *$ & $0.251 *$ & $0.25^{*}$ \\
\hline Length $6-15$ years & & & - & 0.081 & $0.637 * * *$ & $0.514^{* * \star}$ \\
\hline Length $16-25$ years & & & - & 0.117 & 0.739 *** & 0.691 *** \\
\hline Constant & Yes & Yes & Yes & Yes & Yes & Yes \\
\hline Country dummies & Yes & Yes & Yes & Yes & Yes & Yes \\
\hline Time dummies & Yes & Yes & Yes & Yes & Yes & Yes \\
\hline Pseudo R2 & 0.0915 & 0.0916 & 0.0915 & 0.0837 & 0.0667 & 0.0918 \\
\hline Obs: & 442929 & 442929 & 424842 & 7865 & 10064 & 434906 \\
\hline
\end{tabular}

Legend: $\quad{ }^{*} \mathrm{p}<0.05 ;{ }^{* \star} \mathrm{p}<0.01 ;{ }^{* \star *} \mathrm{p}<0.001$

Source: Authors' calculations based on ECHP data; - not applicable.

${ }^{1}$ Only non EU immigrants and natives are included in the regression. EU immigrants are excluded. 
Table 9

The determinants of social relations: "How often do you meet friend or relatives not living with you, whether here at home or elsewhere?"

(logit model) ${ }^{1}$

\begin{tabular}{|c|c|c|c|c|c|c|}
\hline COVARIATES & POOLED & POOLED & NATIVES & $\begin{array}{c}\text { EU } \\
\text { IMMIGRANTS }\end{array}$ & $\begin{array}{c}\text { NON } \\
\text { EU IMM. }\end{array}$ & POOLED $^{2}$ \\
\hline Household size & $-0.072 * \star \star$ & $-0.071 * * \star$ & $-0.072 * * *$ & -0.055 & $-0.065^{\star *}$ & $-0.072^{\text {*** }}$ \\
\hline Age & $-0.025 * \star *$ & $-0.025 * * *$ & $-0.025 * \star \star$ & $-0.028 * * *$ & $-0.027 * * *$ & $-0.025 * * *$ \\
\hline Highest ed. & $0.107^{\star \star *}$ & 0.108 *** & 0.114 *** & -0.043 & 0.180 & $0.113 * * \star$ \\
\hline Intermediate ed. & $0.134 * \star \star$ & 0.134 *** & $0.139 * \star \star$ & 0.112 & 0.041 & $0.131^{* * *}$ \\
\hline Gender & $-0.091 * \star *$ & $-0.092 * * *$ & $-0.086 * * *$ & -0.124 & $-0.197^{*}$ & -0.090 *** \\
\hline Employment & $-0.125 * \star \star$ & $-0.125 * * *$ & $-0.130 * \star \star$ & -0.029 & -0.084 & $-0.129 * * *$ \\
\hline Spouse & $-0.052 * * *$ & $-0.052 * * \star$ & $-0.045 * \star$ & $-0.311 * *$ & -0.082 & $-0.044 * *$ \\
\hline Immigrant & $-0.095^{\star \star}$ & & - & & & \\
\hline Immigrant EU & & 0.008 & - & & & \\
\hline Immigrant non EU & & $-0.161^{\star \star *}$ & - & & & -0.464 *** \\
\hline Length $<5$ years & & & - & 0.033 & 0.033 & -0.016 \\
\hline Length 6-15 years & & & - & 0.378 & 0.471 *** & 0.337 ** \\
\hline Length $16-25$ years & & & - & $0.479 *$ & 0.648 *** & $0.542^{* \star *}$ \\
\hline Constant & Yes & Yes & Yes & Yes & Yes & Yes \\
\hline Country dummies & Yes & Yes & Yes & Yes & Yes & Yes \\
\hline Time dummies & Yes & Yes & Yes & Yes & Yes & Yes \\
\hline Pseudo R2 & 0.086 & 0.119 & 0.086 & 0.124 & 0.054 & 0.086 \\
\hline Obs: & 443313 & 442929 & 425205 & 7875 & 10076 & 435281 \\
\hline
\end{tabular}

Source: Authors' calculations based on ECHP data; - not applicable.

${ }^{1}$ The dependent variable takes a value of 1 for those individuals whose response to the question is either "on most days" or "once/twice a week"

${ }^{2}$ Only non EU immigrants and natives are included in the regression. EU immigrants are excluded 
Table 10

The determinants of social relations: "How often do you meet friend or relatives not living with you, whether here at home or elsewhere?”

(ordered logit model)

\begin{tabular}{|c|c|c|c|c|c|c|}
\hline COVARIATES & POOLED & POOLED & NATIVES & $\begin{array}{c}\text { EU } \\
\text { IMMIGRANTS }\end{array}$ & $\begin{array}{c}\text { NON } \\
\text { EU IMM. }\end{array}$ & POOLED ${ }^{1}$ \\
\hline Household size & -0.035 *** & -0.034 *** & $-0.035^{* * *}$ & 0.003 & -0.057 ** & -0.036 *** \\
\hline Age & $-0.02 * * *$ & $-0.02 * * *$ & $-0.02 * * *$ & $-0.026 * * *$ & $-0.028 * * *$ & $-0.02^{* * *}$ \\
\hline Highest ed. & $-0.09 * * *$ & $-0.089 * * *$ & $-0.084^{\star * *}$ & $-0.232 *$ & -0.019 & $-0.085^{* * *}$ \\
\hline Intermediate ed. & $0.023 *$ & $0.022 *$ & $0.028 *$ & -0.105 & -0.016 & $0.023 *$ \\
\hline Gender & $-0.115^{\star * *}$ & $-0.115^{\star * *}$ & $-0.11 * * *$ & $-0.166 *$ & $-0.22 * * *$ & $-0.114^{* * *}$ \\
\hline Employment & $-0.205^{\star \star \star}$ & -0.206 *** & $-0.209 * * *$ & $-0.165^{*}$ & $-0.123 *$ & $-0.207^{\star \star \star \star}$ \\
\hline Spouse & $-0.189 * * *$ & $-0.189 * * *$ & $-0.187^{* \star *}$ & $-0.381 * * *$ & -0.111 & $-0.183^{* * *}$ \\
\hline Immigrant & $-0.057 *$ & & - & & & -0.362 *** \\
\hline Immigrant EU & & 0.024 & - & & & \\
\hline Immigrant non EU & & $-0.116 * \star \star$ & - & & & \\
\hline Length $<5$ years & & & - & 0.213 & 0.091 & 0.049 \\
\hline Length $6-15$ years & & & - & 0.457 ** & $0.451^{* * *}$ & 0.256 * \\
\hline Length $16-25$ years & & & - & $0.561^{* \star *}$ & $0.568^{* \star *}$ & $0.415^{\text {*** }}$ \\
\hline Constant & Yes & Yes & Yes & Yes & Yes & Yes \\
\hline Country dummies & Yes & Yes & Yes & Yes & Yes & Yes \\
\hline Time dummies & Yes & Yes & Yes & Yes & Yes & Yes \\
\hline Pseudo R2 & 0.0985 & 0.0985 & 0.098 & 0.136 & 0.0674 & 0.0981 \\
\hline Obs: & 442929 & 442929 & 424842 & 7865 & 10064 & 434906 \\
\hline
\end{tabular}

Legend: $\quad{ }^{*} \mathrm{p}<0.05 ;{ }^{* \star} \mathrm{p}<0.01 ;{ }^{* \star *} \mathrm{p}<0.001$

Source: Authors' calculations based on ECHP data; - not applicable.

${ }^{1}$ Only non EU immigrants and natives are included in the regression. EU immigrants are excluded. 


\section{Appendix}

\section{Sample selection and data availability}

Our definition of immigrants is based upon the foreign country of birth (PM007). Amongst the possible alternatives, we choose the variable PM007B, which distinguishes seven different sending regions. Because of this choice, we focus on 8 receiving countries: Austria, Belgium, Denmark, France, Ireland, Italy, Portugal and Spain.

In addition, we consider only individuals in the 24-60 years age group.

We end up with 459,419 observation (440,427 in the sample of natives and 18,992 in the sample of immigrants), on 89,799 individuals (85,835 natives and 3,964 immigrants).

Concerning the dependent variable, we have already seen how data availability is excellent, with a response rate of $99 \%$.

With respect to education, the availability rate is about $95 \%$. More than $1 / 3$ of the missing data are found in France.

Finally, there are only few missing information on employment status and length of stay for immigrants. 


\section{Appendix tables}

Table A1: Availability for "how often do you talk to your neighbour" (Number of observations)

Panel A - Natives

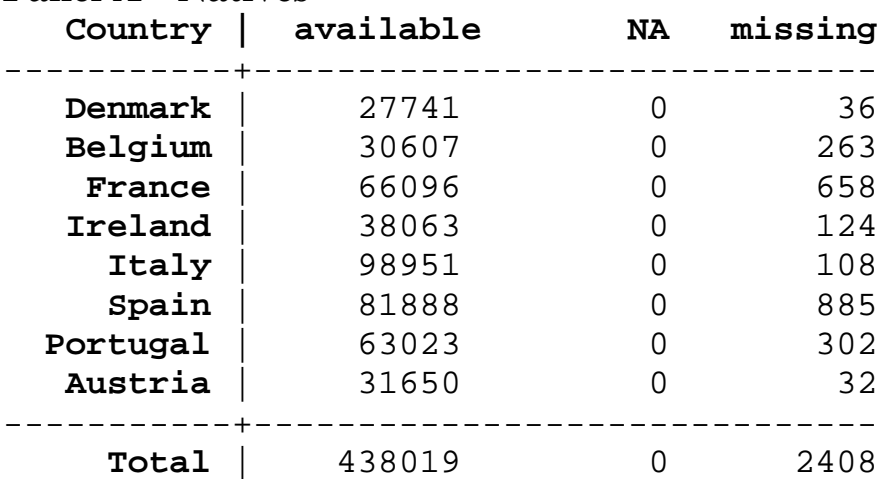

Panel B - Immigrants

\begin{tabular}{|c|c|c|c|}
\hline Country & available & NA & missing \\
\hline & & & \\
\hline Denmark & 1120 & 0 & \\
\hline Belgium & 2855 & $\odot$ & 27 \\
\hline France & 5216 & $\odot$ & 38 \\
\hline Ireland & 2006 & $\odot$ & \\
\hline Italy & 1857 & $\odot$ & \\
\hline Spain & 1480 & $\odot$ & 24 \\
\hline Portugal & 1888 & $\odot$ & 42 \\
\hline Austria & 2426 & $\odot$ & \\
\hline Total & 18848 & $\odot$ & 14 \\
\hline
\end{tabular}

Source: Authors' calculations based on ECHP data

Table A2: Availability for "how often do you meet friends or relatives" (Number of observations)

Panel A - Natives

\begin{tabular}{|c|c|c|c|}
\hline country I & available & NA & missing \\
\hline & & 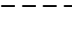 & \\
\hline Denmark & 27762 & $\odot$ & \\
\hline Belgium & 30536 & $\odot$ & 33 \\
\hline France & 66572 & 37 & \\
\hline Ireland & 38009 & 0 & \\
\hline Italy & 98987 & $\odot$ & \\
\hline Spain & 81901 & $\odot$ & 87 \\
\hline Portugal & 63023 & $\odot$ & $3 \odot$ \\
\hline Austria & 31656 & $\odot$ & \\
\hline & & - & \\
\hline Total & 438446 & 37 & 194 \\
\hline
\end{tabular}

Panel B - Immigrants

\begin{tabular}{r|rrr}
\multicolumn{2}{c}{ country | available } & NA & missing \\
Denmark | & 1123 & 0 & 1 \\
Belgium | & 2850 & 0 & 32 \\
France | & 5240 & 0 & 14 \\
Ireland | & 2005 & 0 & 5 \\
Italy | & 1859 & 0 & 3 \\
Spain | & 1480 & 0 & 24 \\
Portugal | & 1888 & 0 & 42 \\
Austria | & 2426 & 0 & 0 \\
\hline
\end{tabular}


$\begin{array}{llll}\text { Total I } & 18871 & 0 & 121\end{array}$

Source: Authors' calculations based on ECHP data

Table A3

The determinants of social relations: “how often do you talk to your neighbour?” (random effect estimates) ${ }^{1}$

\begin{tabular}{|c|c|c|c|c|c|c|}
\hline COVARIATES & POOLED & POOLED & NATIVES & $\begin{array}{c}\text { EU } \\
\text { IMMIGRANTS }\end{array}$ & $\begin{array}{c}\text { NON } \\
\text { EU IMM. }\end{array}$ & POOLED $^{2}$ \\
\hline Household size & $0.084 * \star *$ & $0.084 \star \star * \star$ & $0.083 \star \star \star *$ & 0.119 ** & $0.067 *$ & 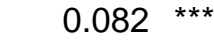 \\
\hline Age & $0.024 * \star *$ & 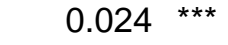 & $0.023 * \star * \star$ & $0.032 * \star * \star$ & 0.007 & $0.023 \star \star \star *$ \\
\hline Highest ed. & $-0.471 * \star * *$ & $-0.47 * \star * *$ & $-0.468 \star \star \star *$ & $-0.343 *$ & $-0.478 * \star * *$ & $-0.471 * * *$ \\
\hline Intermediate ed. & 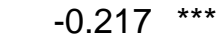 & $-0.218 \star \star \star *$ & $-0.216 \star \star \star *$ & -0.241 & $-0.224 *$ & $-0.218 * \star \star \star$ \\
\hline Gender & $0.349 \star \star \star$ & $0.349 \star \star \star *$ & $0.354 * \star \star$ & $0.316 *$ & $0.237 *$ & $0.35 * * \star$ \\
\hline Employment & 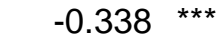 & $-0.339 \star \star \star$ & $-0.336 \star \star \star *$ & 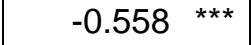 & $-0.298 * \star \star *$ & $-0.335 * * \star$ \\
\hline Spouse & $0.487 \star \star \star *$ & $0.488 * \star \star$ & $0.498 * \star \star$ & $0.323 *$ & $0.289 \star *$ & $0.493 * * \star$ \\
\hline Africa & -0.175 & 0.1 & & & -0.103 & -0.066 \\
\hline America & -0.226 & 0.048 & & & 0.145 & 0.051 \\
\hline Asia & $-0.867 * \star \star *$ & $-0.596 * \star$ & & & $-0.571 * *$ & $-0.503 * *$ \\
\hline Immigrant & $-0.265 * \star * *$ & & & & & $-1.051 * \star *$ \\
\hline Immigrant EU & & $-0.139 *$ & & & & \\
\hline $\begin{array}{l}\text { Immigrant non } \\
\text { EU }\end{array}$ & & $-0.537 * \star \star$ & & & & \\
\hline Length $<5$ & & & & 0.446 * & 0.257 & 0.286 \\
\hline Length 6-15 & & & & 0.159 & $0.669 * \star \star *$ & 0.661 *** \\
\hline Length 16-25 & & & & 0.29 & $0.948 * * *$ & $0.926 * * *$ \\
\hline Constant & Yes & Yes & Yes & Yes & Yes & Yes \\
\hline dummies & Yes & Yes & Yes & Yes & Yes & Yes \\
\hline Time dummies & Yes & Yes & Yes & Yes & Yes & Yes \\
\hline Obs: & 442929 & 442929 & 424842 & 7865 & 10064 & 434906 \\
\hline
\end{tabular}

Legend: $\quad{ }^{*} \mathrm{p}<0.05 ;{ }^{* \star} \mathrm{p}<0.01 ;{ }^{* \star} \mathrm{p}<0.001$

Source: Authors' calculations based on ECHP data

${ }^{1}$ The dependent variable takes a value of 1 for those individuals whose response to the question is either "on most days" or "once/twice a week"

${ }^{2}$ Only non EU immigrants and natives are included in the regression. EU immigrants are excluded 


\section{Table A4}

The determinants of social relations: "how often do you meet friend or relatives not living with you, whether here at home or elsewhere?"

(random effect estimates) ${ }^{1}$

\begin{tabular}{|c|c|c|c|c|c|c|c|}
\hline COVARIATES & POOLED & POOLED & NATIVES & $\begin{array}{c}\text { EU } \\
\text { IMMIGRANTS }\end{array}$ & $\begin{array}{c}\text { NON } \\
\text { EU IMM. }\end{array}$ & \multicolumn{2}{|l|}{ POOLED $^{2}$} \\
\hline Household size & 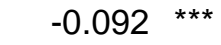 & 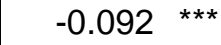 & $-0.094 * * \star$ & -0.081 & $-0.079 \star * *$ & $-0.093 *$ & *** \\
\hline Age & $-0.036 \star \star \star *$ & 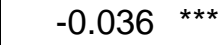 & 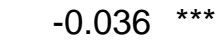 & $-0.04 * \star \star \star$ & $-0.043 \star \star \star *$ & $-0.036 x$ & $\star \star \star *$ \\
\hline Highest ed. & $0.132 * \star \star$ & 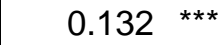 & $0.134 * \star *$ & -0.027 & 0.241 & $0.136 \times$ & $\star * \star$ \\
\hline Intermediate ed. & $0.12 * \star *$ & $0.12 * \star \star *$ & $0.125 * \star *$ & 0.073 & 0.004 & $0.119 *$ & $\star \star \star *$ \\
\hline Gender & $-0.124 * \star \star *$ & $-0.124 * \star * *$ & $-0.12 * \star * *$ & -0.156 & $-0.222 *$ & $-0.124 \times$ & *** \\
\hline Employment & $-0.153 \star \star \star *$ & $-0.153 * \star * *$ & 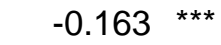 & 0.034 & 0.015 & $-0.158 \times$ & $\star \star \star *$ \\
\hline Spouse & $-0.119 * \star *$ & $-0.119 * \star \star *$ & $-0.116 * \star *$ & $-0.288 *$ & -0.049 & $-0.113 \times$ & $\star \star \star *$ \\
\hline Africa & $-0.233 *$ & -0.219 & & & -0.082 & $-0.387 \times$ & ** \\
\hline America & $-0.648 \quad \star * \star$ & $-0.635 * \star *$ & & & -0.032 & $-0.627 \times$ & *** \\
\hline Asia & $-0.535 * *$ & $-0.522 \star \star *$ & & & -0.309 & -0.454 & * \\
\hline Immigrant & -0.043 & & & & & -0.386 & ** \\
\hline Immigrant EU & & -0.036 & & & & & \\
\hline & & -0.056 & & & & & \\
\hline Length $<5$ years & & & & 0.087 & 0.056 & 0.046 & \\
\hline Length $6-15$ years & & & & $0.55 *$ & 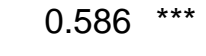 & 0.488 & $\star \star \star ~$ \\
\hline $\begin{array}{l}\text { Lengtr } \\
\text { years }\end{array}$ & & & & $0.565 *$ & $0.827 * \star \star *$ & 0.705 & *** \\
\hline Constant & Yes & Yes & Yes & Yes & Yes & Yes & \\
\hline dummies & Yes & Yes & Yes & Yes & Yes & Yes & \\
\hline Time dummies & Yes & Yes & Yes & Yes & Yes & Yes & \\
\hline Obs: & 443313 & 443313 & 425205 & 7875 & 10076 & 435281 & \\
\hline
\end{tabular}

Legend:

${ }^{*} \mathrm{p}<0.05 ;{ }^{* *} \mathrm{p}<0.01 ;{ }^{* * \star} \mathrm{p}<0.001$

Source: Authors' calculations based on ECHP data

${ }^{1}$ The dependent variable takes a value of 1 for those individuals whose response to the question is either "on most days" or "once/twice a week"

${ }^{2}$ Only non EU immigrants and natives are included in the regression. EU immigrants are excluded 
Table A5

The determinants of social relations: "how often do you talk to your neighbour?" (selectivity corrected estimates) $^{1}$

\begin{tabular}{|c|c|c|c|c|c|c|}
\hline COVARIATES & POOLED & POOLED & NATIVES & $\begin{array}{l}\text { EU } \\
\text { IMMIGRANTS }\end{array}$ & $\begin{array}{c}\text { NON } \\
\text { EU IMM. }\end{array}$ & POOLED ${ }^{2}$ \\
\hline Household size & 0.019 *** & $0.019 \star \star \star \star$ & $0.020 * \star *$ & 0.022 & -0.006 & 0.019 *** \\
\hline Age & $0.008 * \star *$ & $0.008 * * *$ & $0.008 * * *$ & 0.009 * & 0.001 & 0.008 *** \\
\hline Highest ed. & $-0.235 * * *$ & $-0.235 * \star *$ & $-0.229 * \star *$ & -0.281 ** & $-0.268 * \star *$ & $-0.233 * * *$ \\
\hline Intermediate ed. & $-0.094 * * *$ & $-0.094 * * *$ & $-0.090 * \star *$ & -0.168 ** & $-0.140 *$ & $-0.093 * * *$ \\
\hline Gender & $0.131 * \star * *$ & $0.131 * * *$ & $0.132 * * *$ & 0.056 & 0.079 & 0.132 *** \\
\hline Employment & $-0.152 * \star \star *$ & $-0.152 * \star * *$ & $-0.150 * * *$ & $-0.270 \star \star \star *$ & 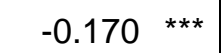 & -0.151 \\
\hline Spouse & 0.182 *** & $0.183 * \star *$ & $0.183 * * *$ & 0.043 & $0.143 *$ & $0.186 * * *$ \\
\hline Africa & -0.034 & 0.065 & & & 0.022 & -0.013 \\
\hline America & -0.036 & 0.062 & & & 0.109 & 0.061 \\
\hline Asia & $-0.324 * \star \star *$ & -0.226 * & & & $-0.229 *$ & -0.176 * \\
\hline Immigrant & $-0.065 *$ & & & & & \\
\hline Immigrant EU & & -0.029 & & & & \\
\hline & & $-0.155 * * *$ & & & & $-0.300 * * *$ \\
\hline Length $<5$ years & & & & -0.008 & 0.022 & 0.015 \\
\hline Length $6-15$ years & & & & -0.216 & 0.254 & 0.203 * \\
\hline years & & & & -0.189 & 0.318 & 0.288 ** \\
\hline $\begin{array}{l}\text { Constant } \\
\text { Country }\end{array}$ & Yes & Yes & Yes & Yes & Yes & Yes \\
\hline dummies & Yes & Yes & Yes & Yes & Yes & Yes \\
\hline Time dummies & Yes & Yes & Yes & Yes & Yes & Yes \\
\hline
\end{tabular}

SELECTION EQUATION

\begin{tabular}{|c|c|c|c|c|c|c|c|c|c|}
\hline Household size & $0.013 \star \star \star *$ & $0.013 * * *$ & 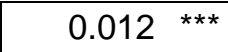 & 0.019 & & 0.025 & * & 0.012 & 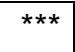 \\
\hline Age & $-0.009 \star * *$ & $-0.009 \star * *$ & $-0.010 * \star *$ & -0.012 & $\star \star \star *$ & -0.008 & $* * *$ & -0.010 & $\star \star * *$ \\
\hline Highest ed. & $0.037 \star \star \star *$ & $0.037 \star \star * *$ & $0.034 * \star * *$ & 0.063 & & 0.120 & * & 0.037 & $\star \star \star \star ~$ \\
\hline Intermediate ed. & 0.011 & 0.011 & 0.005 & 0.032 & & 0.104 & * & 0.008 & \\
\hline Gender & $0.065 * \star \star *$ & $0.065 * \star *$ & $0.062 * \star * \star$ & 0.099 & * & 0.168 & $\star \star \star \star ~$ & 0.065 & $\star \star \star *$ \\
\hline Employment & $0.109 \star \star \star * *$ & $0.109 * \star \star *$ & 0.108 *** & 0.007 & & 0.145 & $\star \star \star \star ~$ & 0.109 & $\star \star \star *$ \\
\hline Spouse & $0.277 * \star *$ & 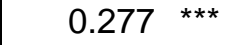 & $0.282 * \star * *$ & 0.249 & $\star \star \star$ & 0.241 & $\star \star \star$ & 0.281 & $\star \star \star *$ \\
\hline Visits & 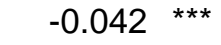 & $-0.042 \star \star * *$ & $-0.043 * \star *$ & -0.055 & $\star \star \star$ & -0.022 & * & -0.042 & $\star \star \star \star$ \\
\hline Minutes & 0.000 & 0.000 & 0.000 & 0.002 & & -0.002 & & 0.000 & \\
\hline Immigrant & $-0.158 * \star \star$ & & & & & & & & \\
\hline $\begin{array}{l}\text { Immigrant EU } \\
\text { Immigrant non }\end{array}$ & & $-0.087 * * *$ & & & & & & & \\
\hline & & $-0.213 * \star \star$ & & & & & & -0.810 & $\star * *$ \\
\hline Length $<5$ years & & & & 0.416 & *** & 0.538 & $\star \star \star$ & 0.547 & $\star \star \star ~$ \\
\hline $\begin{array}{l}\text { Length } 6-15 \text { years } \\
\text { Length } 16-25\end{array}$ & & & & 0.447 & $\star \star \star$ & 0.567 & $\star \star * *$ & 0.590 & 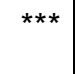 \\
\hline years & & & & 0.689 & $\star \star \star$ & 0.846 & $\star \star \star *$ & 0.854 & $\star \star \star$ \\
\hline $\begin{array}{l}\text { Constant } \\
\text { Country }\end{array}$ & Yes & Yes & Yes & Yes & & Yes & & Yes & \\
\hline dummies & Yes & Yes & Yes & Yes & & Yes & & Yes & \\
\hline Time*Origin & Yes & Yes & Yes & Yes & & Yes & & Yes & \\
\hline Time dummies & Yes & Yes & Yes & Yes & & Yes & & Yes & \\
\hline
\end{tabular}




\section{STATISTICS $^{3}$}

\begin{tabular}{|c|c|c|c|c|c|c|}
\hline$\rho$ & 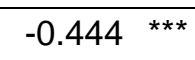 & 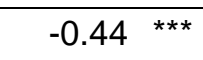 & 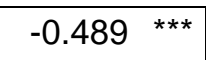 & -0.774 & -0.391 & $-0.441 * \star \star *$ \\
\hline$x^{2}$ & 66.087 & 66.002 & 63.339 & 0.186 & 0.793 & 66.394 \\
\hline $\mathrm{p}$ value & 0.000 & 0.000 & 0.000 & 0.667 & 0.373 & 0.000 \\
\hline Observations & 359800 & 359800 & 345830 & 6041 & 7823 & 353653 \\
\hline Censored obs & 42883 & 42883 & 40786 & 870 & 1208 & 41994 \\
\hline
\end{tabular}

Legend: $\quad{ }^{\star} \mathrm{p}<0.05 ;{ }^{* \star} \mathrm{p}<0.01 ;{ }^{* \star \star} \mathrm{p}<0.001$

Source: Authors' calculations based on ECHP data

${ }^{1}$ The dependent variable takes a value of 1 for those individuals whose response to the question is either "on most days" or "once/twice a week"

${ }^{2}$ Only non EU immigrants and natives are included in the regression. EU immigrants are excluded

${ }^{3}$ The $\rho$ statistics is the correlation coefficient between the selection and the behavioural equations. The $\chi^{2}$ statistics tests for the significance of the selectivity correction 
Table A6

The determinants of social relations: "how often do you meet friend or relatives not living with you, whether here at home or elsewhere?"

(selectivity corrected estimates) $^{1}$

\begin{tabular}{|c|c|c|c|c|c|c|c|}
\hline COVARIATES & POOLED & POOLED & NATIVES & \begin{tabular}{|c|} 
EU \\
IMMIGRANTS
\end{tabular} & $\begin{array}{c}\text { NON } \\
\text { EU IMM. }\end{array}$ & \multicolumn{2}{|l|}{ POOLED $^{2}$} \\
\hline Household size & $-0.044 * \star \star \star$ & $-0.044 * \star \star *$ & $-0.044 * \star \star$ & -0.014 & -0.049 ** & $-0.045 * *$ & $* \star \star$ \\
\hline Age & $-0.014 * * *$ & $-0.014 * * *$ & $-0.014 * * *$ & $-0.016 * \star *$ & $-0.016 * \star *$ & $-0.014 * \star$ & 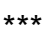 \\
\hline Highest ed. & $0.035 * *$ & $0.035 * *$ & $0.037 * *$ & -0.077 & $0.129 *$ & 0.039 ** & ** \\
\hline Intermediate ed. & $0.070 * \star \star$ & $0.070 * \star \star$ & $0.070 * * *$ & 0.046 & 0.062 & 0.069 ** & 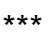 \\
\hline Gender & $-0.043 * * *$ & $-0.043 * * *$ & $-0.040 * * *$ & -0.062 & -0.095 & $-0.043 * *$ & *** \\
\hline Employment & $-0.066 * * *$ & $-0.066 * * *$ & $-0.066 * * *$ & -0.050 & -0.044 & $-0.067 * *$ & *** \\
\hline Spouse & -0.002 & -0.002 & 0.004 & $-0.147 *$ & 0.005 & 0.001 & \\
\hline Africa & -0.074 & -0.058 & & & -0.031 & $-0.129 *$ & * \\
\hline America & $-0.283 * * *$ & $-0.267 * *$ & & & -0.002 & -0.264 ** & ** \\
\hline Asia & $-0.281 * *$ & $-0.265 *$ & & & -0.115 & $-0.220 *$ & * \\
\hline Immigrant & -0.001 & & & & & & \\
\hline Immigrant EU & & 0.009 & & & & & \\
\hline $\begin{array}{l}\text { Immigrant non } \\
\text { EU }\end{array}$ & & -0.019 & & & & $-0.255 * *$ & ** \\
\hline Length $<5$ years & & & & -0.074 & 0.155 & 0.111 & \\
\hline $\begin{array}{l}\text { Length } 6-15 \text { years } \\
\text { Length } 16-25\end{array}$ & & & & 0.107 & $0.375 * \star \star$ & 0.280 ** & ** \\
\hline years & & & & 0.229 & $0.488 * * *$ & 0.412 ** & *** \\
\hline Constant & Yes & Yes & Yes & Yes & Yes & Yes & \\
\hline dummies & Yes & Yes & Yes & Yes & Yes & Yes & \\
\hline Time dummies & Yes & Yes & Yes & Yes & Yes & Yes & \\
\hline
\end{tabular}

SELECTION EQUATION

\begin{tabular}{|c|c|c|c|c|c|c|c|}
\hline Household size & $0.013 * \star * *$ & $0.013 * \star * *$ & $0.012 * \star \star *$ & 0.016 & 0.025 & * & 0.012 *** \\
\hline Age & $-0.009 * \star *$ & $-0.009 * \star *$ & $-0.010 * \star *$ & $-0.013 * \star * *$ & -0.008 & $\star \star \star \star ~$ & $-0.010 * * \star$ \\
\hline Highest ed. & $0.034 * * *$ & $0.035 * * *$ & $0.031 * * *$ & 0.063 & 0.119 & * & $0.035 * * *$ \\
\hline Intermediate ed. & 0.009 & 0.009 & 0.003 & 0.029 & 0.105 & * & 0.006 \\
\hline Gender & $0.067 * \star \star *$ & 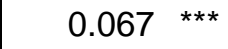 & $0.064 * * *$ & $0.099 *$ & 0.169 & $\star \star \star \star ~$ & 0.067 *** \\
\hline Employment & $0.109 * * *$ & $0.108 * * *$ & $0.107 * * *$ & 0.007 & 0.145 & 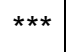 & 0.108 *** \\
\hline Spouse & $0.278 * \star *$ & $0.278 * \star \star$ & $0.283 * \star *$ & $0.255 \star \star \star *$ & 0.243 & $\star \star \star$ & 0.282 \\
\hline Visits & $-0.040 * \star \star *$ & $-0.040 * \star *$ & $-0.041 * \star *$ & $-0.048 * \star *$ & -0.021 & * & $-0.040 * \star \star x$ \\
\hline Minutes & 0.000 & 0.000 & 0.000 & 0.002 & -0.002 & & 0.000 \\
\hline Immigrant & $-0.161 * \star \star *$ & & & & & & \\
\hline $\begin{array}{l}\text { Immigrant EU } \\
\text { Immigrant non }\end{array}$ & & $-0.087 * \star \star$ & & & & & \\
\hline & & $-0.217 * \star \star *$ & & & & & $-0.814 * \star \star \star x$ \\
\hline Length $<5$ years & & & & $0.413 * * *$ & 0.535 & $\star \star \star \star$ & $0.546 * * *$ \\
\hline $\begin{array}{l}\text { Length } 6-15 \text { years } \\
\text { Length } 16-25\end{array}$ & & & & $0.448 * \star \star *$ & 0.570 & $\star \star * *$ & $0.593 * * *$ \\
\hline years & & & & $0.695 * \star *$ & 0.845 & $\star \star \star$ & $0.856 * * *$ \\
\hline $\begin{array}{l}\text { Constant } \\
\text { Country }\end{array}$ & Yes & Yes & Yes & Yes & Yes & & Yes \\
\hline dummies & Yes & Yes & Yes & Yes & Yes & & Yes \\
\hline Time*Origin & Yes & Yes & Yes & Yes & Yes & & Yes \\
\hline Time dummies & Yes & Yes & Yes & Yes & Yes & & Yes \\
\hline
\end{tabular}




\section{STATISTICS $^{3}$}

\begin{tabular}{|c|c|c|c|c|c|c|}
\hline$\rho$ & 0.06 & 0.062 & 0.087 & -0.198 & 0.276 & 0.047 \\
\hline$\chi^{2}$ & 0.35 & 0.388 & 0.581 & 0.267 & & 0.177 \\
\hline $\mathrm{p}$ value & 0.554 & 0.534 & 0.446 & 0.606 & & 0.674 \\
\hline Observations & 359986 & 359986 & 346007 & 6048 & 7825 & 353832 \\
\hline Censored obs. & 42883 & 42883 & 40786 & 870 & 1208 & 41994 \\
\hline
\end{tabular}

Legend: $\quad{ }^{*} \mathrm{p}<0.05 ;{ }^{* \star} \mathrm{p}<0.01 ;{ }^{* \star \star} \mathrm{p}<0.001$

Source: Authors' calculations based on ECHP data

${ }^{1}$ The dependent variable takes a value of 1 for those individuals whose response to the question is either "on most days" or "once/twice a week"

${ }^{2}$ Only non EU immigrants and natives are included in the regression. EU immigrants are excluded

${ }^{3}$ The $\rho$ statistics is the correlation coefficient between the selection and the behavioural equations. The $\chi^{2}$ statistics tests for the significance of the selectivity correction 